\title{
Islamic Contracts for Home Financing: A Comparative Analysis
}

\section{Aulia Fitria Yustiardhi,}

Mahdiah Aulia, and

Reni Oktavia Permatasari

\section{International Islamic University Malaysia (IIUM)}

\begin{abstract}
Home financing is widely needed by many people across different countries. Through the years, Islamic banks have developed several models for home financing to address the growing demand from customers. Two products that Islamic banks use extensively are Murabahah and Bay Bithaman Ajil (BBA) which in practice have similar characteristics to their conventional counterparts, which leads to criticism from Islamic scholars. Alternative Islamic home financing schemes that have been introduced to the market in recent years include Musharakah Mutanaqisah (MM), Ijarah Muntahiya Bit Tamlik (IMBT) and Istisna. These three financial products have different features that could overcome the weaknesses of Murabahah and Bay Bithaman Ajil. However, these three financial contracts are not without limitations. This paper provides a theoretical overview of these contracts. Further studies should discuss more practical issues that could promote the use of these contracts.
\end{abstract}

Keywords: Islamic home financing; Musharakah Mutanaqisah; Ijarah Muntahiya Bit Tamlik; Istisna; Shariah 


\section{Introduction}

Islamic home financing is an alternative financial product for homebuyers for financing their purchase of homes. Most of the Islamic homes financing products currently offered by Islamic banks are based on the principle of Bay' Bithaman Ajil (BBA), Murabahah and Commodity Murabahah. However, there have been some controversies involving BBA because of the use of the base lending rate as the benchmark for interest rates (Ariff and Rosly, 2011). Similarly, some scholars criticise the use of interest rates as benchmark in Murabahah contracts (Mohd Yusof et al., 2011; Sairally, 2002). Because of the controversial use of interest rates, Islamic banks started to adopt other Islamic concepts such as Musharakah Mutanaqisah (MM), Ijarah Muntahiya Bit Tamlik (IMBT) and Istisna. This paper examines Islamic home financing in Malaysia, with a special focus on Musharakah Mutanaqisah, Ijarah, and Istisna. This paper aims to compare these Islamic financial instruments for home financing based on data collected from peer reviewed journal articles, industry reports, and statistics published by authoritative bodies.

\section{Murabahah and its Controversies}

The central bank of Malaysia, Bank Negara Malaysia, defines Murabahah as a sale and purchase contract that "shall not be terminated unilaterally by any of the contracting parties" (Bank Negara Malaysia, 2013, p. 9) because it is binding in nature. Based on the element of trust in disclosing the cost and mark-up, Murabahah has the advantage of simplicity and relatively low risk compared to other Islamic financing modes (Sairally, 2002). Nonetheless, Murabahah has been criticised for the following reasons.

The existence of the asset

Assets to be traded under a Murabahah contract are required to be identifiable and deliverable. An asset in a Murabahah contract should fulfil the general rule of sale pertaining to the existence of the subject matter at the time of contract. Housing projects or properties under construction are not permissible under the principle of Murabahah. This condition excludes housing developers or homebuilders who do not have the completed housing, restricting them from using this mode of financing.

Determining the mark-up price in the long-term

Murabahah is a sale transaction based on a cost-plus profit basis and the price should be based on disclosed acquisition cost and a profit margin, which could be a definite sum in money terms or a percentage of the cost. Most of the Islamic banks determine the profit or mark-up price for the Murabahah contract using Interest rates as Benchmarks (Lahsasna, 2014). According to Bank Negara Malaysia (2013, p. 13), "the mark-up may be determined either in the form of an absolute amount or a certain percentage of the acquisition cost or a reference rate such as the Base Lending Rate(BLR), the Base Financing Rate (BFR), Kuala Lumpur Interbank Offered Rate (KLIBOR) or Cost of Funds (COF)". The practice of using interest rates as mark up is common in conventional banking but interest-based financing is prohibited under Shariah law (Sairally, 2002).

International Journal of Management and Applied Research, 2019, Vol. 6, No. 4 
Early payment discount and penalty in the event of default

As a general principle in Islamic law, default or late payments are not penalised while an early payment discount is not given to a customer who pays ahead of schedule. The reasons for not charging a penalty were based on the principle that the agreed price should not be increased or decreased over time (Sairally, 2002). Such banking practices lead to a risk of default because customers do not face financial loss in the event of late payment or non-payment. In reference to Bank Negara Malaysia (2013, p. 140), "In the event of default, the seller may purchase the same asset or part thereof from the defaulting purchaser in cash at a mutually agreed price. The proceeds of the sale may be used to settle the outstanding debt on the basis of set-off (muqassah)". Settling outstanding debt on the basis of set-off is in line with Shariah principles. Additionally, Bank Negara Malaysia (2015b) also suggests the Islamic banks grant ibra (rebate) to customers who settle their debt prior to the agreed settlement period as stipulated in the agreement concluded by both parties.

\section{Alternative Contracts}

In addition to Murabahah/BBA home financing products, Islamic banks also offer other Islamic contracts, namely, Musharakah Mutanaqisah (MM), Ijarah Muntahiya Bit Tamlik (IMBT) and Istisna'. Each contract will be discussed below.

\subsection{Musharakah Mutanaqisah}

Musharakah Mutanaqisah (MM) or diminishing Musharakah is a form of partnership in which one partner promises to buy the equity share of the other partner gradually until the title of the equity is completely transferred to him (AAOIFI, 2015). It is commonly used in many countries, including European, Asian, and Middle East and African countries (Moriguchi et al., 2016). According to Bank Negara Malaysia (2015a), two or more parties may enter a Musharakah on a particular asset or venture, one partner may lease his or her share of the Musharakah asset to other partners or gradually purchase the partner's share of the asset at market value, fair value or any price to be agreed by the partners over an agreed period of time. Under the Musharakah Mutanaqisah contract, the customer pays a down payment as his or her equity share while the remaining balance is paid off by the bank. The bank leases the house so acquired to the customer and the bank receives rental from the customer in return (Smolo and Hassan, 2011). The customer and bank co-own the property with an initial pre-determined share of ownership, for example: the client owns 20 percent while the bank owns 80 percent of the property. The customer will gradually redeem the equity share of the bank through the financing period until the full amount is paid. The Musharakah Mutanaqisah is ended when the property is 100 percent owned by the customer and the ownership title is transferred to the customer.

Diminishing partnership in a home financing contract represents a joint venture between the bank and the customer where they buy the house together (Smolo and Hassan, 2011). Instead of using interest-based financing, it uses the rental index or the house price index (Mohd Yusof et al., 2011). Musharakah Mutanaqisah consists of three contracts: Musharakah, Ijarah and bay (IFSB, 2015). The bank and customer establish joint ownership, the house is leased to the customer and the share of the bank

International Journal of Management and Applied Research, 2019, Vol. 6, No. 4 
is gradually diminished over time until the equity is completely transferred to the customer. Although these three contracts are permissible under Shariah law it is difficult to combine different contracts due to legal complexity. The validity of the combined contracts is contingent upon the attributes of the combined contracts (Arbouna, 2007). According to the Islamic Financial Services Board (IFSB) (2015, p. 132), "It is also not permitted for one contract to be entered into as a condition for concluding the other". The Islamic jurists have different opinions with regards to the validity of the combination of contracts, whether such ownership transfer could take place (Arbouna, 2007).

\subsubsection{Risk involved in Musharakah Mutanaqisah}

The Capital Adequacy Framework for Islamic Banks issued by Bank Negara Malaysia (2012) provides guidelines on minimum capital requirements cover the risk of losing invested capital from entering into contracts that are based on diminishing Musharakah. These include mapping risk grades into three categories and each of these categories will be associated with a specific risk weight.

In a study of risk perception around Islamic financing, Ahmed and Khan (2007) found that diminishing Musharakah is perceived by the bankers to have a high credit risk and market risk. This view is supported by Bank Negara Malaysia (2012) in that Islamic banking institutions are exposed to credit risk. Credit risk occurs when one party does not make full payment on time as contractually agreed which results in loss of income for another party (Ahmed and Khan, 2007). Market risk, on the other hand, is defined by Bank Negara Malaysia (2012, p. 235) as "the risk of losses in on- and off-balance sheet positions arising from movements in market prices". In practice, Islamic financial institutions apply the principle of diminishing Musharakah for the gradual transfer of property ownership to the customer without allowing sharing of capital gains that may arise as a result of house price inflation or increased property values (Dar, 2007). However, in the event of depreciation in the property value, the customer continues to pay for the full amount as contractually agreed.

\subsection{Ijarah Muntahiya Bit Tamlik (Lease ending with ownership)}

Ijarah Muntahiya Bit Tamlik (also known as Ijarah muntahia bi tamleek) is a contractual arrangement consisting of Ijarah (lease) and tamlik (ownership). Bank Negara Malaysia (2018, p. 18) defines jarah muntahiyah bi tamlik as "an ijarah contract which ends with the lessee owning the leased asset and shall contain a mechanism for the transfer of ownership of the leased asset from the lessor to the lessee during or at the end of the lease period". This financial transaction is quite similar to diminishing Musharakah because the ownership title is transferred to the client at the end of the lease period when the agreed sum of rental is paid in full. The purchase price of the leased property could be determined in the following ways: first, the contracting parties may mutually agree a nominal value, a prevailing market price at the time of the purchase or a specific method of calculating the purchase price (Bank Negara Malaysia, 2018). The legitimacy of the contract can be referred to the AAOIFI Shariah Standard No. 9, which clearly indicates that Ijarah Muntahiya Bit Tamlik is permissible.

International Journal of Management and Applied Research, 2019, Vol. 6, No. 4 


\subsubsection{Risk involved in Ijarah Muntahiya Bit Tamlik}

According to Salem (2013), financial institutions which implement Ijarah Muntahiya Bit Tamlik contracts for home financing are exposed to credit risk and market risk. Furthermore, since the asset belongs to the financial institution until the end of the lease period, the financial institution is exposed to operational risk and liabilities arising from ownership while the lessee is liable for financial loss relating to the use of leased asset (Akkizidis and Khandelwal, 2008). As a lessor, the Islamic bank is exposed to credit risk if the lessee fails to pay the rental amount in accordance with the agreed terms. Islamic financial institutions are also exposed to credit risk from the lessee if the lessee cannot compensate for the losses arising from the disposal of assets. Additionally, the financial institutions are also exposed to market price fluctuation upon the transfer of ownership (Salem, 2013), especially in the case of long-term fixed rental payment or a decline in the value of the leased asset.

In practice, the ownership title is transferred from the seller to the client and the property or asset remains in the ownership of the client (Kureshi and Hayat 2015). Mainly, this is because financial institutions should not be in the business of selling real estate and a preponderance of tangible physical assets would affect the assessment of the bank as per current banking laws (van Greuning and Brajovic-Bratanovic, 2009). Moreover, the bank would have to provide a replacement or compensation to the client in the event of product recall (Kureshi and Hayat 2015). This adds complexities to the banking operations and thus Islamic financial institutions often avoid taking ownership which slightly deviates from the Shariah principle of Ijarah Muntahiya Bit Tamlik.

\subsection{Istisna}

Istisna refers to commissioned manufacture, where a manufacturer or builder agrees to produce items according to agreed specifications, with payment dates and price specified in the contract (World Bank, 2017). This contractual arrangement is widely used for real estate project financing and infrastructure financing (Chu and Muneeza, 2019).

As a general rule of Shariah, it is not permissible to sell items that do not exist yet (AAOIFI, 2015). This is with the exception of Istisna because the contract involves a sale of manufactured goods for future delivery based on specification. The legitimacy of the Istisna contract is grounded in the Quran and unanimously approved by Muslim jurists. Surah Al-Baqarah verse 275 and Al-Maidah verse 1 imply the general permissibility of sales contracts including Istisna contract. The contemporary rulings for Istisna and parallel Istisna are based on AAOIFI Shariah Standard No. 11, which covers Istisna and parallel Istisna transaction.

Parallel Istisna consists of two separate Istisna contracts whereby the first Istisna contract involves a homebuyer (consumer) and the bank, and the second contract involves the bank and the manufacturer/contractor of the real estate. These two contracts are independent of each other and the bank is liable for financial losses if the builder is unable to complete the housing project on time (Akkizidis and Khandelwal, 2008). The repayment period varies according to terms and condition and payment can

International Journal of Management and Applied Research, 2019, Vol. 6, No. 4 
be made by instalments, during construction or after completion (Hasmawati and Mohamad, 2019).

Istisna may be combined with other Islamic contracts such as Ijarah (lease) and Musharakah Mutanaqisah (Diminishing Partnership). The combined use of these contracts allows banks and builders to mobilise funds and mitigate risks. For example, the expansion of Madinah Airport in Saudi Arabia utilised Istisna and Ijarah as long term financing arrangements (World Bank, 2017). First, the project company transfer certain rights to financiers (lenders) under a procurement agreement (Istisna) and the payment is disbursed based on an agreed schedule. The lenders also have concession agreements (Ijarah) with the project company and receive lease rentals as income. Such an arrangement is commonly used in capital intensive infrastructure projects (Chu and Muneeza, 2019).

Under a combination of Istisna and Musharakah Mutanaqisah, the client and the bank create a Musharakah pool under the principle of shirkahtul-milk and jointly enter into an Istisna contract with the contractor/developer for the specified asset construction (Bank Negara Malaysia, 2015a). The bank then leases its share of ownership to the customer. During the financing period, ownership is gradually transferred to the client until full payment is made.

\subsubsection{Risk involved in Istisna}

Islamic financial institutions which offer Istisna are exposed to liquidity, operational and market risks (Akkizidis and Khandelwal, 2008). Similarly to Ijarah Muntahiya Bit Tamlik, market price fluctuation may result in a different property value at the delivery date. The financial institutions are also liable for non-delivery in the event of failure to complete the construction project on time, cost overruns and force majeure events (IFSB, 2015). Such operational risk leads to liquidity risk because the cash flow of the institution may be affected if the project is not completed at the selling date. These risks are not typical for conventional banks because the completion risk is typically borne by the project company.

Although the Istisna' contract is considered permissible by Islamic scholars, several Shariah issues arises over the implementation of Parallel Istisna contracts. The first issue is pricing: Istisna is a forward sale contract in which the commodity is not produced yet and thus determining the price of the commodity is subject to speculation, which is prohibited under Shariah law.

To overcome this issue and avoid gharar, Bank Negara Malaysia (2015b) released the Guidelines on Istisna, which stated that the price of the Istisna asset must be based on mutual agreement by the contracting parties (agreed price) at the time of entering into the contract. Moreover, the agreed price of the asset may be revised after entering into the contract and before delivery of the Istisna asset to the purchaser.

\section{Discussion}

In this section, issues relating to Islamic home financing will be discussed. It looks at the complexities of financing property under construction, the likely risks involved, rebates, penalties and use of interest rates for benchmarking.

International Journal of Management and Applied Research, 2019, Vol. 6, No. 4 


\section{Properties under construction}

Purchasing a house under construction is more complicated than buying a newly built house under Islamic law. Istisna is an Islamic contract for homebuyers to purchase a house under construction; however, this contractual arrangement may leads to additional risks for the Islamic financial intuition. Bank Negara Malaysia (2015a) stated that for the purpose of acquiring an asset under construction, financial institutions may arrange Musharakah Mutanaqisah with Istisna whereby the partners enter into an Istisna contract with a third party. The Istisna principle allows the selling of something that is not constructed or is under construction. Therefore, unlike other contracts, an Istisna contract will be more suitable as a home financing product when the asset is not available yet or not a ready-stock house.

\section{Determining the mark-up price in the long-term}

The Musharakah Mutanaqisah contract is more flexible than the Murabahah and Ijarah Muntahiya Bit Tamlik contract in terms of pricing. In Musharakah Mutanaqisah, the bank can adjust the rental price according to the current market price and thus both client and bank are not exposed to market risk. The client makes periodic instalments based on a market valuation, and the purchase price is based on the market value at that time, which has a lower level of market risk compared to Murabahah/BBA financing. The price of the property is pre-determined in an Istisna contract. The basis of the Shariah requirement is that the price be known is to remove uncertainty that may lead to dispute (AAOIFI, 2015). Deferred payment is allowed in an Istisna contract.

\section{Settlement on early redemption or in the event of default}

In Ijarah home financing, the bank shall grant Ibra (rebate) on any amount payable by the customer in respect of any payment due under the facility taken up by the customer with the bank. In the event of default on an Ijarah contract, based on the stipulation by Bank Negara Malaysia (2018) the bank may sell the leased asset to the customer on a credit basis at a mutually agreed price and may hold the asset as collateral to guarantee maturity and punctual payments of the purchase price. If the customer or lessee defaults on the obligation to pay the purchase price, the bank may exercise its right to liquidate the collateral or may claim the remaining purchase price under the credit sale, net of Ibra (rebate), if usable, any delay in rental fees and costs related to liquidation of the collateral. Similarly, the seller of Istisna may waive part of the outstanding agreed price to the homebuyer in the event of early settlement (Bank Negara Malaysia, 2015b).

The pricing of Musharakah Mutanaqisah and Ijarah Muntahiya Bit Tamlik reflect the market price of the commodity and thus the client will receive a discount on early settlement. In the event of early redemption, the bank will discharge the remaining ownership and the customer pays the remaining balance. The same treatment may be implemented in the event of default case.

\section{Using Interest rate as Benchmark}

The current practice for determining the rental in Musharakah Mutanaqisah is still based on conventional benchmarks such as KLIBOR and LIBOR (Redzuan et al., 2018). In practice, it is challenging to use market value as benchmark due to price

International Journal of Management and Applied Research, 2019, Vol. 6, No. 4 
volatility (Smolo and Hassan, 2011). There are some alternatives to benchmark being proposed to reflect the market value such as using the market rental yield and the Islamic Interbank Benchmark Rate (IIBR) proposed by Thomson Reuters.

In an Ijarah Muntahiya Bit Tamlik contract, the benchmark for the rental rate of an asset is negotiable between the lessor and the lessee. This can be a fixed rate for all ownership until maturity or flexible rates that vary according to calculation methods. Furthermore, both contracting parties are bound by the requirements until the contract due date. Any changes to the agreed floating interest rates will be considered as risks taken by both parties based on the upfront mutual agreement. Determination of rates can be made for all lease periods or in stages. The rate may also be fixed or floating depending on its suitability as acknowledged by both lessee and lessor (AAOIFI, 2015).

Risks

The application of Musharakah Mutanaqisah, Ijarah Muntahiya Bit Tamlik and Istisna contracts may expose the Islamic bank to various types of risk, namely credit, market, liquidity, operational and completion risk (Akkizidis and Khandelwal, 2008). These risks occur at different stages of transactions and are subject to external change. Therefore, the Islamic bank has to establish comprehensive and sound risk management policies and procedures, systems and internal control to mitigate risks. Table 1 provides a comparison between different Islamic home financing contracts.

Table 1: Comparison between Contracts for Home Financing

\begin{tabular}{|c|c|c|c|c|}
\hline & Murabahah & $\begin{array}{l}\text { Musharakah } \\
\text { Mutanaqisah }\end{array}$ & $\begin{array}{c}\text { Ijarah Muntahiya } \\
\text { Bit Tamlik }\end{array}$ & Istisna \\
\hline House type & $\begin{array}{c}\text { New built house; } \\
\text { Second-hand } \\
\text { house }\end{array}$ & $\begin{array}{l}\text { New built house; } \\
\text { Second-hand house; } \\
\text { House under } \\
\text { construction } \\
\text { (combined with } \\
\text { Istisna) }\end{array}$ & $\begin{array}{l}\text { New-built house; } \\
\text { Second-hand house }\end{array}$ & $\begin{array}{l}\text { House under } \\
\text { construction }\end{array}$ \\
\hline $\begin{array}{l}\text { Contracting } \\
\text { parties }\end{array}$ & $\begin{array}{l}\text { Buyer (client); } \\
\text { Seller (bank) }\end{array}$ & $\begin{array}{l}\text { Client; } \\
\text { Bank; } \\
\text { Builder }\end{array}$ & $\begin{array}{c}\text { Client; } \\
\text { Bank; } \\
\text { Builder }\end{array}$ & $\begin{array}{l}\text { Client; } \\
\text { Bank; } \\
\text { Builder }\end{array}$ \\
\hline $\begin{array}{l}\text { Asset } \\
\text { ownership }\end{array}$ & $\begin{array}{l}\text { Client has full } \\
\text { ownership }\end{array}$ & $\begin{array}{l}\text { Client and bank co- } \\
\text { own the property }\end{array}$ & $\begin{array}{l}\text { Bank has full } \\
\text { ownership }\end{array}$ & $\begin{array}{l}\text { Client has full } \\
\text { ownership }\end{array}$ \\
\hline $\begin{array}{l}\text { Financing } \\
\text { value }\end{array}$ & Cost price & $\begin{array}{l}\text { Bank's ownership } \\
\text { portion }\end{array}$ & Cost price & Cost price \\
\hline $\begin{array}{l}\text { Profit for } \\
\text { bank }\end{array}$ & Mark up & Rental & Rental & Mark up \\
\hline $\begin{array}{l}\text { Shariah } \\
\text { issue }\end{array}$ & $\begin{array}{l}\text { Use interest rate } \\
\text { for benchmarking }\end{array}$ & $\begin{array}{c}\text { Property } \\
\text { maintenance }\end{array}$ & $\begin{array}{c}\text { Transfer of asset } \\
\text { ownership }\end{array}$ & $\begin{array}{l}\text { Calculation of } \\
\text { pricing }\end{array}$ \\
\hline $\begin{array}{l}\text { Instrument } \\
\text { type }\end{array}$ & Debt-based & Equity-based & Debt-based & Debt-based \\
\hline Risk for bank & Credit risk & $\begin{array}{l}\text { Credit risk; } \\
\text { Market risk }\end{array}$ & $\begin{array}{c}\text { Credit risk; } \\
\text { Market risk; } \\
\text { Operational risk }\end{array}$ & $\begin{array}{c}\text { Credit risk; } \\
\text { Market risk; } \\
\text { Non-delivery } \\
\text { risk }\end{array}$ \\
\hline
\end{tabular}

International Journal of Management and Applied Research, 2019, Vol. 6, No. 4 


\section{Conclusion}

Innovation is crucial for the survival and growth of all businesses. Although the Islamic financial sector has been growing steadily over the years, the sector has been constrained by limited product innovation. To meet evolving market demands, Islamic financial institutions should be more responsive and take a more proactive action.

This paper explores a range of Shariah compliant home financing: Musharakah Mutanaqisah, Istisna and Ijarah. These Islamic financial instruments are also suitable for project financing; however, care must be taken to ensure Shariah compliance especially when combining multiple Islamic contracts.

The advantage of using Musharakah Mutanaqisah and Ijarah Muntahiya Bit Tamlik is their affordable mode of asset acquisition for financial consumers, especially when compared to Murabahah and BBA home financing (Smolo and Hassan, 2011). Istisna, on the other hand, allows fund mobilisation among different stakeholders.

However, these Islamic financial instruments are not without challenges and limitations. First and foremost, these instruments may not be compatible with current banking laws (Smolo and Hassan, 2011). A bank should not be involved in real estate acquisition in order to protect depositors from the associated risks (van Greuning and Brajovic-Bratanovic, 2009). Moreover, the abovementioned Islamic contracts may result in additional risks and administrative burdens for the Islamic financial institutions, with little return compared to other modes of financing.

More concerted efforts among Islamic scholars, banking professionals and practitioners in the real estate sector are needed. Future research should focus on ways to mitigate risks for both financier and finance seeker; for instance, payment mechanisms or business models that adhere to Shariah teachings.

\section{References}

1. Ahmed, H. and Khan, T. (2007), "Risk management in Islamic banking", in: Hassan, M. K. and Lewis, M. K. (Ed.), Handbook of Islamic Banking, Cheltenham: Edward Elgar Publishing Limited, pp. 144-160. https://doi.org/10.4337/9781847205414.00019

2. Arbouna, M. B. (2007), "The combination of contracts in Shariah: A possible mechanism for product development in Islamic banking and finance", Thunderbird International Business Review, Vol. 49, No. 3, pp. 341-369. https://doi.org/10.1002/tie.20147

3. Accounting, Auditing and Governance Standards for Islamic Financial Institutions (AAOIFI) (2015), Shariah Standard, Bahrain: AAOIFI.

International Journal of Management and Applied Research, 2019, Vol. 6, No. 4 
4. Akkizidis, I. and Khandelwal, S. K. (2008), Financial Risk Management for Islamic Banking and Finance, UK: Palgrave Macmillan. https://doi.org/10.1057/9780230598751

5. Ariff, M. and Rosly, S. A. (2011), "Islamic Banking in Malaysia: Unchartered Waters", Asian Economic Policy Review, Vol. 6, No. 2, pp. 301-319. https://doi.org/10.1111/j.1748-3131.2011.01208.x

6. Bank Negara Malaysia (2012), Capital Adequacy Framework for Islamic Banks [Online] available from:

http://www.bnm.gov.my/guidelines/01_banking/01_capital_adequacy/02_gl_cap ital_adequacy_framework_islamic.pdf [accessed on 9 September 2019].

7. Bank Negara Malaysia (2013), Murabahah, [Online] available from: http://www.bnm.gov.my/guidelines/05_shariah/CP_Murabahah_122013.pdf [accessed on 9 September 2019].

8. Bank Negara Malaysia (2015a), Musyarakah. [Online] available from: http://www.bnm.gov.my/guidelines/05_shariah/Musyarakah.pdf [accessed on 9 September 2019].

9. Bank Negara Malaysia (2015b), Istisna. [Online] available from: http://www.bnm.gov.my/index.php?ch=57\&pg=137\&ac=467\&bb=file [accessed on 9 September 2019].

10. Bank Negara Malaysia (2018), Ijarah. [Online] available from: http://www.bnm.gov.my/index.php?ch=57\&pg=137\&ac=530\&bb=file [accessed on 9 September 2019].

11. Chu, J. and Muneeza, A. (2019), "Belt and Road Initiative and Islamic Financing: The Case in Public Private Partnership Infrastructure Financing", International Journal of Management and Applied Research, Vol. 6, No. 1, pp. 24-40. https://doi.org/10.18646/2056.61.19-002

12. Dar, H. (2007), "Incentive Compatibility of Islamic Financing”, in: Hassan, M. K. and Lewis, M. K. (Ed.), Handbook of Islamic Banking, Cheltenham: Edward Elgar Publishing Limited, pp. https://doi.org/10.4337/9781847205414.00015

13. Hasmawati, A. and Mohamad, A. (2019), "Potential application of Istisna' financing in Malaysia", Qualitative Research in Financial Markets, Vol. 11, No. 2, pp.211-226. https://doi.org/10.1108/QRFM-07-2018-0083

14. Islamic Financial Services Board (IFSB) (2015), Islamic Finance for Asia: Development, Prospects, and Inclusive Growth, Co-publication of the Asian Development Bank and the Islamic Financial Services Board.

International Journal of Management and Applied Research, 2019, Vol. 6, No. 4 
15. Kureshi, H. and Hayat, M. (2015), Contracts and Deals in Islamic Finance: A User's Guide to Cash Flows, Balance Sheets, and Capital Structures, Singapore: John Wiley and Sons.

16. Lahsasna, A. (2014), Shariah Issues and Resolutions in Contemporary Islamic Banking and Finance, Malaysia: IBIFM Publication.

17. Mohd Yusof, R., Kassim, S., Shabri A. Majid, M. and Hamid, Z. (2011), "Determining the viability of rental price to benchmark Islamic home financing products", Benchmarking: An International Journal, Vol. 18 No. 1, pp. 69-85. https://doi.org/10.1108/14635771111109823

18. Moriguchi, T.; Khattak, M. A.; Farhan, M.; Firdaus, M.; Worasutr, A.; Hakim, A. L.; Musthafa, F.; Muneeza, A. (2016), "Contemporary Practices of Musharakah in Financial Transactions", International Journal of Management and Applied Research, Vol. 3, No. 2, pp. 65-76. https://doi.org/10.18646/2056.32.16-005

19. Redzuan, N. H., Kassim, S., and Abdullah, A. (2018), "Rental Yield As An Alternative to Interest Rate In Pricing Musyarakah Mutanaqisah Home Financing-The Case For Malaysia”, Al-Shajarah: Journal of the International Institute of Islamic Thought and Civilization, pp. 69-88.

20. Sairally, B.S. (2002), "Murabahah financing: Some controversial issues", Review of Islamic Economics, No. 12, pp. 73-86.

21. Salem, R. A. (2013), Risk Management for Islamic Banks, Edinburgh: Edinburgh University Press.

22. Smolo, E., and Hassan, K. M. (2011), "The potentials of musharakah mutanaqisah for Islamic housing finance", International Journal of Islamic and Middle Eastern Finance and Management, Vol. 4, No. 3, pp. 237-258. https://doi.org/10.1108/17538391111166476

23. World Bank (2017), Mobilizing Islamic Finance for Infrastructure PublicPrivate Partnerships [Online] Available from: http://documents.worldbank.org/curated/en/898871513144724493/MobilizingIslamic-finance-for-infrastructure-public-private-partnerships [Accessed on 12 September 2019].

24. van Greuning, H. and Brajovic-Bratanovic, S. (2009), Analyzing Banking Risk: A Framework for Assessing Corporate Governance and Risk Management, Washington DC: World Bank Publications.

International Journal of Management and Applied Research, 2019, Vol. 6, No. 4 